I.はじめに

筆者らは，4，5，6才の幼児の聴力操失特性と，幼児をとリまく環境音の測定・分析を行った。2 その結果，幼览の㯖力特性を考虑した，適切な音量域と周波数特性をもつ環境音を与えろことによ， て，幼肾の聴力特性の発達に良い効果をもたらすことがわか，た。また，短期間の追路測定によって も，タドタドしい幼児の会話が，聴力損失の減少した子供から，少しずつ消えるように感じう北た。 近年，幼児の知能の開発を目的とした，音楽環境づくりが提唱さ北ているがる，上記のことを考虑 することにより，より良い効果が期待できるであるう・(かし：こ北うに闌するものの報告の調查や 考察の对象幼児の範囲内にとどまっており，乥北以後の発達については触水られていない。

以下，幼児以後の㯖力の発逹と学力の向上との関係を推定する手掛りの一っとして，11才16才の各

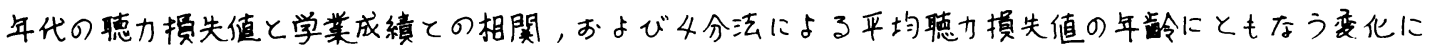
つリて泟定したので，䢁告する。

\title{
2. 实输方法
}

6才(4名)，11才(10名)，16才(16名) およu゙23才(5君)の計35名(70耳)を被倹者とし， 通常の洋室(学校の教空，慅音レベル50〜65 phone，C一特性)を测定埸所として使用した。

リォン製オージオメータ（AA-39A型）用い，右耳左耳の順に下降法により，気道最小可輽值を制 定した。

\section{3. 实駼結果}

11 オの個Rの児童の，4分法による平均聴力損失值 *)(以下，简单に平均㯖力操失値とかく）と学期末の 成績評洒 $^{* \text { (*) }}$ ( 教科の平均点) との関係は図一I(a)の ようになった。四からもわかる通り，かなり強り負の 相関を示した。また，16才についても，平均聴力損失 値と学期末成縤玶洒（５教科の平均点）との関係は圆 -I（b）の如く，比較的強川負の相関を示すことがわか った。

6才，23才の各層の平均聴力損失值は，策者らが以 前に測定したものりよUへ5dB程度高りものになっ ていた。测定埸所の違うこと，骚音レベルが以前(45 〜 50phone，(-特性)よりやゃ高めであることを考虐し ，以前に测定にた4.5,6才の各年代の平均㯖力損失值 ，今回测定した11 オ，16才の各年代の平均㯖力損失值

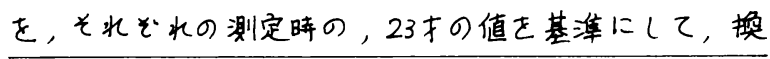

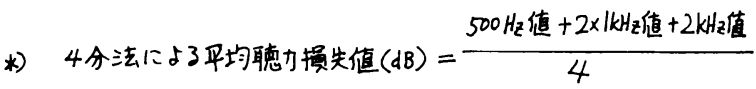

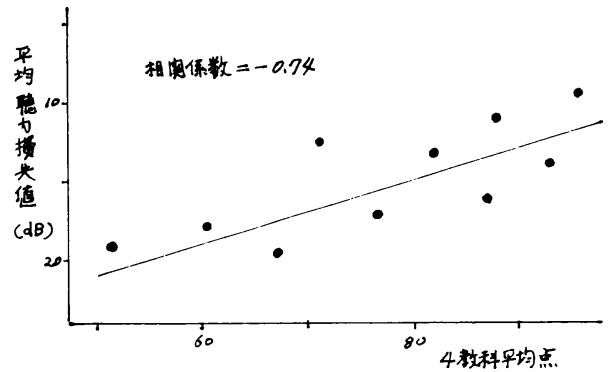

(a) $11 \hbar$

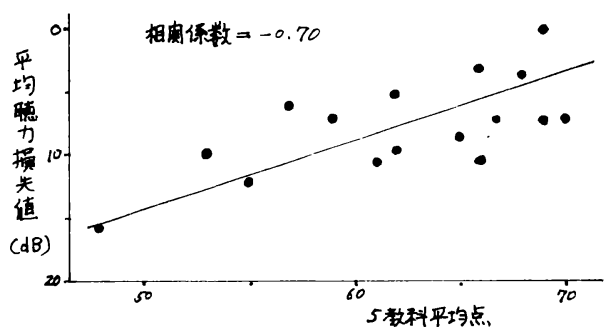

(b) $16 才$

国一４４分法による平均噹力揁失值と 成績との関係

**)测定值は昭和55年7月上旬より中旬にかけて测免し たもので，各アの成䜌呼洒も昭和55年度1学期末のものを使用太。 
算しなるした値を求めて，对数目盛の横軸に年踣をと

リ，平均㯖力摃失値との関係をグラつに画くと，四-2 となった。

\section{4. 考察}

まずはじめに，平均㯖力損失の年龄度存(图一2)に

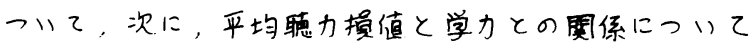
考之る。

聴力損失特性を決定可るのけ，中耳の昇压特性と耳 の最小可㯖值がよく一致することから，主に外耳・中 耳伝音系の特性によるものと見なさ北ている で，中耳伝晋系について考之る。四一2の破線部分推 定年部特性で，生掕間もない新生児の鼓膜が極めて大

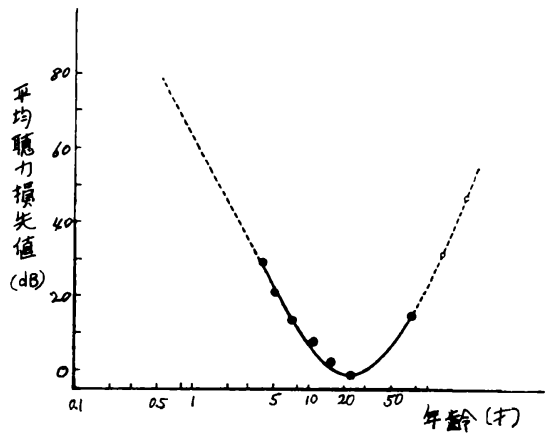

図-2平均聴力損失と年龄との送係 ₹い(Keith 5) )とす北ば，曲線の一部の補正は必要と思わ北る。(かし，Wedenberg 6)のベル音に

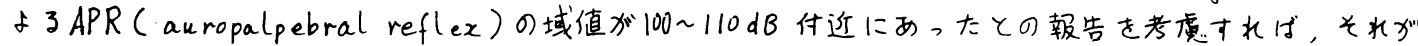
純音による聴力揁失の值でないとしても，ほぼ一致することから，20才以下の特性には，聴音時の集 中度が一要因として含ま北ているものと思わ北る。

学習は，㯖觉と視觉を至な媒介として，知裁(情辄)を受け入北ることによってなされる。すると

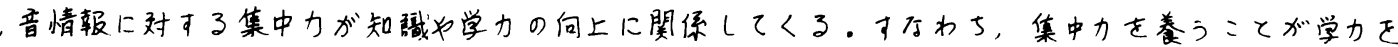
のばす上で大切である，という通常の考え方を容浔するならば，㯖力損失と学力との間に角の相䦔関 係俵水る。

16才の全教科の総合铗洒と平均㯖力掑失值との相関は，11才のものに比べてゃや弱いものとなって

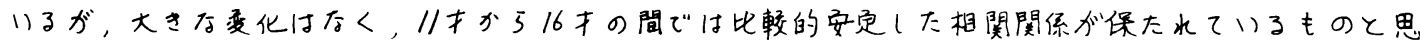

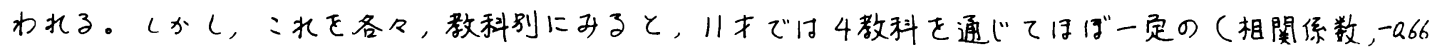

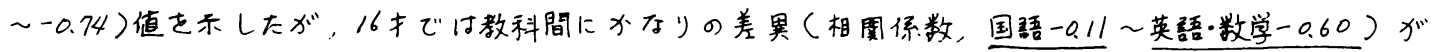
表北た。:北时，成長とともに，子供の学習に对可る姿熟が，周国依存型から，自我の発逹にとも7 い，自立しうとする傾向にあるために生ずるものと思わ北る。すなわ了，雑多厉音の中わら自分に 必要な情郝を選び受け入北る(または，この逆の）判断力が，川キでは，まだまだ未熟であるて考え 今北了。

\section{5. 結铻}

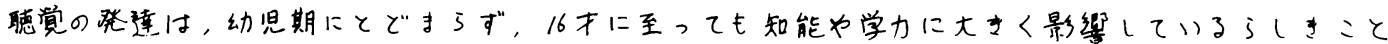

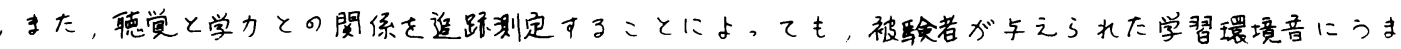
く遥合できる集团とそうでない集团の2つに，比較的はっきりと分けることのできることから，㯖力

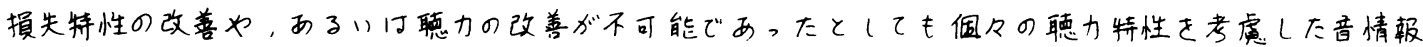
を与之ることによって，并の後の学力の向上に良い効果をもたうすであるうことが期街できそうであ 3.

文 解

1)鈴木，吉久，林他：生体の受容置特性の解析一德觉の特性につい2，㻴境科学統合研年報5(1977)31-35。

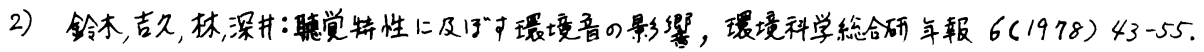

3) Miller, C.L., Morse, P.A : Selective adaptation effects in infant speech perception paradigms, J. Acoust. Soc.Aner. 65 (1979)

4) 西子通住学会: 婹觉と音声, 電子通保学会 (1966) 166 . L $789-790$

5) Keith, R.W.: Impedance Audiometry with Neonates, Acta. Otolar. 97(1973) 465-467

6) Wedenbeng, F.: Auditory tests on newborre infants, Acta. Otolar. $46(1956) 446$ 